\title{
IMPACT OF SMARTPHONE APPLICATIONS ON POLITICAL BEHAVIOUR OF YOUTH
}

\author{
Majid ul Ghafar ${ }^{1 *}$, Muhammad Shahzad ${ }^{2}$ and Neelam Zahir ${ }^{3}$ \\ ${ }^{1}$ Department of Communication \& Media Studies, Hazara University, Pakistan \\ ${ }^{2}$ Dept. of Media Studies, The Islamia University of Bahawalpur, Pakistan \\ ${ }^{3}$ Department of Communication Studies, The University of Sargodha, Pakistan
}

\begin{abstract}
This research study is conducted to explore the impact of Smartphone applications on political behavior of youth. The study is conducted based on serving standard questionnaire for data collection and analysis. The aim of the study is to explore the impact of Smartphone applications like Facebook, Twitter, WhatsApp, ChatON, Imo, Videos, Music, and many other applications. Youth using Smartphone to Chat, Share ideas, information, upload videos and pictures. Smartphone also provides different social media applications to its users for chatting, sharing information and many other purposes. In this research study 200 male and 200 female students of two universities were selected as respondents. The findings show that respondents use Smartphone since 3 to 4 years. The findings also reveal that majority of the youth use Smartphone to interact with friends. The exclusive analysis of findings reveals that majority of the respondents use Facebook very frequently to share information about politics as compared with other applications. The work also indicates that Smartphone applications are very popular among the youth. They not only use these applications for chatting and call making but also for political information. This research study further indicates that Smartphone application affects the voting behavior of youth. They not only interact with each other but also share and discuss political contents.
\end{abstract}

Keywords: Smartphone, Youth, Political Behavior, Impact

\section{Introduction}

Communication is the essence and omnipresent phenomenon which deals every aspect of human life. Sociocultural, political, diplomatic, religious development of human being depends mainly on successful communication techniques and effective communication machines used in the process. Technological breakthrough and scientific discoveries, especially in the field of communication have not only changed the traditional communication techniques but also shrunk the world into a 'global village'. From individual life to international relationships modern communication facilities and technique have changed human behavior and attitude towards entire process of relationship between individual, groups, society and world community.

Smartphone communication is one of the latest facilities and in countries like Pakistan it is not more than a decade old. In Pakistan with passage of time Smartphone companies increased in number and expanded their technology at growing rate. IBM (Internet Business Machine) first ever Smartphone Simon introduced in the market in 1993, eventually it shifted from being phone centric that can handled only limited software to data centric that can perform multiple functions i.e. instant messaging, picture messaging, video and audio playback, Global Positioning System (GPS), games, a video camera, picture and video editing. The purpose behind the introduction of Smartphone is to facilitate its users by introducing different internet applications. This shift was exemplified by the introduction of first-generation IPhone in 2007, and by release of Linux based Android operating system in 2008 .

On the world map, Asia is a vast continent and half of the mobile world is in Asia. Egypt tops the compound annual growth rate (worldwide) by having greatest increase in number of mobile phone users followed by Oman, Sudan, Bangladesh, Mozambique, Iran and Pakistan. In terms of mobile phone growth, Pakistan ranks 
7th in the world and $2^{\text {nd }}$ in Asia (Portio research 2013). 67\% of the Pakistan's total population owns a mobile phone and 23\% of them own a Smartphone (Portio research 2013). There are 30 million internet users in Pakistan while half of them browse internet via mobile phones (Ansri, 2013).

\section{Smartphone Applications}

After the introduction of mobile phone and its popularity among its users encourage the mobile phone companies to introduce different social media applications. These applications facilitate the users to chat, text, talk and business. Smartphone applications like Facebook, Twitter, ChatON, Imo, WhatsApp and Viber are playing very important role not only to facilitate its users but also give them opportunity to share and participate in political activities.

Currently, there are six companies working in Pakistan i.e. Zong, Mobilink, Telenor, Warid and Ufone. These companies lower their rates of packages to increase the subscribers. And as a result "on the list of top ten countries as a mobile phone subscribers Pakistan stands at $10^{\text {th }}$ position, In 2003 there were 300,000 users of mobile phone but in 2008 it increased to 90 million"(http://www.google.com/techlahore.).

\section{Importance of political communication:}

In the modern world politics and political issues encompass a broad scope of political communication and demonstrate the ubiquity of political communication in contemporary life and in non-electoral periods. Internal and external political communication channels are the nerves of any government. Political system cannot function without effective networks of such channels capable of transmitting political messages (Lee Kaid, 2004). Political communication deals not only with election campaigns but also enable the voters to make an informed decision in order to play their effective part in a democratic process.

\section{Significance of the Study}

These technological advances and availability of different mobile packages attracted millions of Smartphone subscribers, especially the youth. It has attracted the youth to use Smartphone technology with internet facility not only to chat but also to comment, call and for many other social, economic and academic purposes. Smartphone technology in Pakistan has also attracted the youth to share their ideas, liking and disliking regarding the politics, political leadership and other personal matters. Political communication is one of the most important subjects in communication and media studies. Different political parties use social media and advance technologies for their political campaign and address the voters through different social media websites. In Pakistan different political parties using Facebook, twitter and other online networking to encourage the youth for casting vote in their favor and these parties also update their achievements in order to create soft corner and favor to their policies.

\section{Objectives of the Study}

1) To explore purposes of using Smartphone by the youth;

2) To explore how much Smartphone applications provide information about politics;

3) To explore impact on political behavior through Smartphone.

\section{Review of Literature}

Communication activities in their manifold forms along with diversified means of communication such as Radio, TV, Internet, Smartphone, Film, books, newspapers and many others have reshaped human lives in all areas. Communication media technological development sparing very rapidly have succeeded in bringing the global setup on tip of fingers. Smartphone is the most rapidly accessible personal device that penetrated into our 
day to day life from personal contacts to engage the respondent in political matters. This facility not only increased the speed and scope of interaction in the developed societies but also undertaken new phenomenon of communication from one to one or from one to many.

In a developing country like Pakistan use of Smartphone has been increasingly advanced in recent years. In this regard, internet facility $3 \mathrm{G}, 4 \mathrm{G}$ has been introduced and several mobile companies like Ufone, Zong, Telenor, Warid, Jaz have been offering different internet packages to their users. Commonly known social media and their usage have been increasing since 2006. It is assumed that, "two third of American aged 16 to 29 years of age would choose a mobile phone ahead of a landline phone, compared to 31 percent of those aged over 50 years" (Mobile and Youth, 2004). Today's use of Smartphone is not popularly common among the well educated people but also used by less educated for different purposes. Social media through Smartphone help their users also to keep themselves well informed of different political events and parties in the country. Amenda Lenhart, 2007 argues that "teen send instant messages at least several times a week and each session last half hour and involves three or more friends".

Hermkens, 2011 very rightly says "one vital aspect of social media is that it uses Smartphone and web based technologies to create highly interactive platforms through which individuals and communities share, discuss and modify user- generated content".

Today's generation is very active in adoption of Smartphone. Like any other machines and motives of its use have both merits and demerits. According to Hermkens, "one vital aspect of social media is that it uses mobile and web-based technologies to create highly interactive platforms through which individuals and communities share, discuss and modify user-generated content" (Hermkens, 2011). They use it for different purposes. Use of Smartphone varies from society to society in view of local culture or religious sensitivities. For example, in view of use of Smartphone with camera is not allowed due to privacy risks (Murugaboopathi et al, 2012). In this regard one of the studies conducted in Midwestern University for usage of Smartphone and its impact on studies determined that,"students who frequently use mobile phone and social media on mobile has negative impact and lacking of intelligence in note taking and point scoring while students who do not use text messaging and other applications are more intelligent in notes taking in the class and almost their scores are 90\%" (Kuznekoff and Titsworth, 2013).

At present mobile phone has become a social and entertainment hub. There is a difference in use of mobile phone by young and aged people. Use of social media is increasing day by day in Pakistan, not only by the well educated people but also by the less educated people use social media for different purposes. The use of social media on mobile phone is also helping the users to keep themselves informed regarding different political happenings in the country.

Apart from physical negative effects of overwhelming use of Smartphone, it provides direct access in mentioning ongoing family and friend's interaction. In the existing setup of social strata Smartphone has become a social and entertainment hub. In Pakistan social media facilities are increasingly used by the youth. Apart from use of Smartphone at personal level political parties in Pakistan have created their party web pages to communicate and propagate their policies to the voters, especially the youth for motivation and exchange of ideas.

\section{Methodology}

Survey research technique is used for data collection and population is consisted of youth. Sample of this research work is very carefully selected keeping in view the scope and reasonable responses of the respondents. Male and female students of two different Universities of Pakistan located in two provinces are selected to control as much variables as possible. 400 students of the above said Universities of both gender are selected and served close-ended questionnaires. The collected data is analyzed by using SPSS (Statistical Package for Social Sciences) software to draw the results about the issue under this research. 


\section{Findings}

Table 1 across gender reveals that $44 \%$ female respondents are using Smartphone since 1 to 2 years while as compared to male respondents $28 \%$, similarly $30 \%$ respondents both male and female using Smartphone 3 to 4 years with equal percentile. The exclusive analysis shows that $21 \%$ male respondents using Smartphone since 5 to 6 years as compared to female respondents $12 \%$ (Table 1 ).

Table 1 : Demographic Wise Users' History of Smartphone Usage

\begin{tabular}{ccc} 
Category & \multicolumn{2}{c}{ Gender } \\
\cline { 2 - 3 } & Male & Female \\
\hline 1-2 Year & $* 28$ & 44 \\
\hline 4-Mar & 30 & 30 \\
\hline 6-May & 21 & 12 \\
\hline 8-Jul & 10 & 7 \\
\hline $\begin{array}{c}\text { More 'than } \\
8\end{array}$ & 13 & 7 \\
\hline $\mathrm{N} \#$ & 200 & 200 \\
\hline
\end{tabular}

The exclusive analysis of the data reveals that overall $39 \%$ respondents very much use Smartphone to interact with friends while $37 \%$ much use to interact with family, similarly $24 \%$ respondents use it to interact with coworkers. The exclusive analysis of data across gender reveals that $72 \%$ male respondents use Smartphone to interact with friends as compared with $67 \%$ females and across aged group it has been observed that $69 \%$ respondents with low age group use Smartphone to interact with friends as compared with high age group $67 \%$. It has also been observed through empirical data that $67 \%$ female respondents use Smartphone to interact with family as compared with $62 \%$ male respondents and across age groups the data reveals that both age groups use Smartphone to interact with family members with equal percentile $27 \%$. Interaction with coworkers the exclusive data reveals that $44 \%$ male respondents much use Smartphone to interact with coworkers as compared with female respondents $33 \%$ with significant difference. Across age groups it has been observed that $39 \%$ respondents of low age group use Smartphone to interact with coworkers as compared with high age group 36\% with no significant difference (Table 2).

Table 2: Interactional Purpose of Using Smartphone

\begin{tabular}{lccccc} 
Category & Overall & \multicolumn{2}{c}{ Gender } & \multicolumn{2}{c}{ Age } \\
\cline { 2 - 6 } & & Male & Female & $\mathbf{2 5}$ & 25+ \\
\hline $\begin{array}{l}\text { WITH } \\
\text { FRIENDS }\end{array}$ & & & & & \\
Very Much & $* 39$ & 48 & 31 & 40 & 36 \\
\hline Much & 30 & 24 & 36 & 29 & 31 \\
\hline Somewhat & 18 & 17 & 20 & 18 & 19 \\
\hline Rarely & 11 & 11 & 10 & 11 & 10 \\
\hline Not at all & 2 & 1 & 4 & 1 & 5 \\
\hline WITH FAMILY & & & & 27 \\
Very Much & 27 & 26 & 29 & 27 & 34 \\
\hline Much & 37 & 36 & 38 & 38 & 20 \\
\hline Somewhat & 21 & 24 & 19 & 22 & \\
\hline
\end{tabular}




\begin{tabular}{lccccc} 
Rarely & 12 & 13 & 11 & 10 & 16 \\
\hline Not at all & 3 & 3 & 4 & 3 & 4 \\
\hline WITH COWORKERS & & & & \\
Very Much & 14 & 16 & 13 & 15 & 13 \\
\hline Much & 24 & 28 & 20 & 24 & 23 \\
\hline Somewhat & 23 & 18 & 29 & 22 & 26 \\
\hline Rarely & 24 & 24 & 25 & 24 & 23 \\
\hline Not at all & 15 & 16 & 13 & 14 & 16 \\
\hline
\end{tabular}

The exclusive analysis of data reveals that overall $73 \%$ respondents use Smartphone for the purpose of text messaging followed by $66 \%$ for Information and $62 \%$ for music. Similarly $60 \%$ respondents use Smartphone for the purpose of call making and $60 \%$ for education with equal percentile. The exclusive analysis of data $79 \%$ male respondents use Smartphone for the purpose of text messages as compared with female respondents $68 \%$ with significant difference and across age groups it has been observed that $75 \%$ lower age group use Smartphone for the purpose of text messaging as compared with high age group respondents $70 \%$ with significant difference. It has also been observed thorough empirical data that $69 \%$ male respondents much use Smartphone for the purpose of call making as compared with female respondents $50 \%$ with significant difference (Table 3 ).

Table 3: Purpose of using Smartphone

\begin{tabular}{|c|c|c|c|c|c|}
\hline \multirow[t]{2}{*}{ Category } & \multirow[t]{2}{*}{ Overall } & \multicolumn{2}{|c|}{ Gender } & \multicolumn{2}{|c|}{ Age } \\
\hline & & Male & Female & 25 & $25+$ \\
\hline \multicolumn{6}{|l|}{ Call Making } \\
\hline Very Much & $* 29$ & 35 & 23 & 27 & 39 \\
\hline Much & 31 & 34 & 27 & 32 & 26 \\
\hline Somewhat & 21 & 17 & 26 & 22 & 18 \\
\hline Rarely & 16 & 12 & 21 & 15 & 15 \\
\hline Not at all & 3 & 3 & 3 & 3 & 3 \\
\hline \multicolumn{6}{|l|}{$\begin{array}{l}\text { Text } \\
\text { Messaging }\end{array}$} \\
\hline Very Much & 42 & 50 & 35 & 43 & 39 \\
\hline Much & 31 & 29 & 33 & 32 & 31 \\
\hline Somewhat & 17 & 14 & 20 & 14 & 18 \\
\hline Rarely & 7 & 6 & 8 & 6 & 9 \\
\hline Not at all & 4 & 3 & 5 & 4 & 4 \\
\hline \multicolumn{6}{|l|}{ Music } \\
\hline Very Much & 33 & 37 & 32 & 36 & 30 \\
\hline Much & 29 & 29 & 28 & 28 & 29 \\
\hline Somewhat & 22 & 19 & 23 & 19 & 23 \\
\hline Rarely & 12 & 12 & 12 & 11 & 14 \\
\hline Not at all & 5 & 5 & 6 & 5 & 5 \\
\hline \multicolumn{6}{|l|}{ Information } \\
\hline Very Much & 32 & 35 & 30 & 35 & 24 \\
\hline Much & 34 & 34 & 34 & 34 & 33 \\
\hline
\end{tabular}




\begin{tabular}{lccccc} 
Somewhat & 21 & 21 & 21 & 20 & 26 \\
\hline Rarely & 8 & 7 & 9 & 6 & 13 \\
\hline Not at all & 5 & 4 & 6 & 5 & 5 \\
\hline Education & & & & & \\
Very Much & 28 & 31 & 29 & 28 & 26 \\
\hline Much & 32 & 33 & 30 & 33 & 26 \\
\hline Somewhat & 22 & 19 & 21 & 21 & 24 \\
\hline Rarely & 9 & 10 & 8 & 7 & 14 \\
\hline Not at all & 10 & 9 & 12 & 10 & 11 \\
\hline
\end{tabular}

The exclusive analysis of data reveals that overall $70 \%$ respondents consider Facebook Smartphone application frequently provide political information as compared with Twitter 52\% followed by $50 \%$ WhatsApp. The exclusive data reveals that $76 \%$ male respondents frequently consider Facebook Smartphone application provides information about politics as compared with female respondents $65 \%$ with significant difference. Across age group it has been observed that respondents $72 \%$ with lower age group consider Facebook frequently share information about politics as compared with higher age group $64 \%$ with significant difference. The exclusive analysis of data also reveals that $52 \%$ male respondents very frequently consider WhatsApp Smartphone application provide information about politics as compared with female respondents $48 \%$ with significant difference (Table 4).

Table 4: Extent of Information Provide by Smartphone Application regarding politics

\begin{tabular}{lccccc}
\multirow{2}{*}{ Category } & Overall & \multicolumn{2}{c}{ Gender } & \multicolumn{2}{c}{ Age } \\
\cline { 3 - 6 } & & Male & Female & $\mathbf{2 5}+$ \\
\hline Facebook & & & & & \\
\hline $\begin{array}{l}\text { Very } \\
\text { Frequently }\end{array}$ & 37 & 43 & 31 & 39 & 30 \\
\hline Frequently & 33 & 33 & 34 & 33 & 34 \\
\hline Somewhat & 16 & 15 & 18 & 16 & 17 \\
\hline Rarely & 6 & 6 & 6 & 6 & 6 \\
\hline Not at all & 8 & 4 & 11 & 5 & 14 \\
\hline Twitter & & & & & \\
Very & & & & & \\
Frequently & 35 & 36 & 35 & 37 & 28 \\
\hline Frequently & 17 & 16 & 22 & 17 & 17 \\
\hline Somewhat & 16 & 19 & 12 & 17 & 12 \\
\hline Rarely & 13 & 13 & 14 & 13 & 15 \\
\hline Not at all & 19 & 17 & 18 & 16 & 29 \\
\hline WhatsApp & & & & & \\
Very & & & & & \\
Frequently & 30 & 27 & 33 & 31 & 25 \\
\hline Frequently & 20 & 25 & 15 & 21 & 16 \\
\hline Somewhat & 16 & 17 & 16 & 16 & 17 \\
\hline Rarely & 13 & 12 & 15 & 13 & 13 \\
\hline Not at all & 21 & 20 & 22 & 18 & 30 \\
\hline & & & & & \\
\hline
\end{tabular}


The exclusive analysis of data reveals that overall majority of the respondents $72 \%$ strongly agree that Facebook Smartphone application affects the political behavior of youth followed by $66 \%$ WhatsApp, $65 \%$ Video, and $60 \%$ Twitter. Across age group it has been observed through data that respondents with low age group $68 \%$ agree that Messenger Smartphone application as compared with high age group $61 \%$ with significant difference.

The exclusive analysis of data reveals that $79 \%$ male respondents agree that Facebook Smartphone application affect the political behavior of youth as compared with female respondents $66 \%$ with significant difference (Table 5).

Table 5: Effects of Smartphone Applications on Political Behavior

\begin{tabular}{|c|c|c|c|c|c|}
\hline \multirow[t]{2}{*}{ Category } & \multirow[t]{2}{*}{ Overall } & \multicolumn{2}{|c|}{ Gender } & \multicolumn{2}{|c|}{ Age } \\
\hline & & Male & Female & 25 & $25+$ \\
\hline \multicolumn{6}{|l|}{ Facebook } \\
\hline Strongly Agree & 36 & 49 & 24 & 35 & 39 \\
\hline Agree & 36 & 30 & 42 & 37 & 32 \\
\hline Neutral & 15 & 12 & 19 & 16 & 14 \\
\hline $\begin{array}{l}\text { Strongly } \\
\text { Disagree }\end{array}$ & 7 & 6 & 7 & 6 & 8 \\
\hline Disagree & 6 & 5 & 8 & 6 & 8 \\
\hline \multicolumn{6}{|l|}{ Twitter } \\
\hline Strongly Agree & 38 & 38 & 39 & 38 & 38 \\
\hline Agree & 22 & 25 & 19 & 27 & 21 \\
\hline Neutral & 18 & 18 & 19 & 12 & 21 \\
\hline $\begin{array}{l}\text { Strongly } \\
\text { Disagree }\end{array}$ & 9 & 9 & 9 & 10 & 7 \\
\hline Disagree & 13 & 12 & 15 & 13 & 14 \\
\hline \multicolumn{6}{|l|}{ Videos } \\
\hline Strongly Agree & 45 & 46 & 45 & 45 & 44 \\
\hline Agree & 20 & 23 & 18 & 24 & 20 \\
\hline Neutral & 16 & 14 & 18 & 12 & 17 \\
\hline $\begin{array}{l}\text { Strongly } \\
\text { Disagree }\end{array}$ & 8 & 8 & 8 & 8 & 8 \\
\hline Disagree & 12 & 11 & 12 & 11 & 12 \\
\hline \multicolumn{6}{|l|}{ WhatsApp } \\
\hline Strongly Agree & 38 & 33 & 45 & 38 & 37 \\
\hline Agree & 28 & 32 & 25 & 30 & 24 \\
\hline Neutral & 16 & 17 & 12 & 15 & 20 \\
\hline $\begin{array}{l}\text { Strongly } \\
\text { Disagree }\end{array}$ & 8 & 10 & 7 & 8 & 9 \\
\hline Disagree & 10 & 9 & 11 & 10 & 11 \\
\hline
\end{tabular}

\section{Summary and Conclusion}

This research study was aimed at to find out the "Impact of Smartphone Applications on Political Behavior of Youth". Survey method is used to collect data from respondents, 200 male and 200 female University students by serving close-ended questionnaire. In this regard, two different Universities students one from Khyber Pakhtunkhuwa and the other from the Punjab University of Pakistan were selected. The study is undertaken to 
investigate the habits of the youth using Smartphone and Smartphone applications like Facebook, Twitter, WhatsApp, Imo, ChatON, Viber etc. Review of literature was done in order to comprehend the issue under investigation.

Empirical analysis of data reveals that majority of respondents have been using Smartphone from 3 to 4 years (See Table 1). Data analysis also reveals that majority of the respondents use Smartphone to interact with their friends. However, majority of female respondents use Smartphone to interact with their families rather the friends. This shows significance difference of usage behavior (See Table 2). The data further reveal that majority of the respondents use Smartphone applications for different purposes. In this context, male respondents frequently use Smartphone applications for text messages as compared with female respondents which show significant difference (See Table 3).

This is also reveals that male gender uses Smartphone more text messaging as compared with female gender. In this regard, the data shows that Facebook Smartphone application provides more information on politics as compared with other applications (See Table 4). Majority of the youth also agrees that Facebook Smartphone application effect political behavior of youth more than any other application (See Table 5).

The above findings are in line with other studies reveal that Smartphone applications not only provide political information but also affect the political behavior of the youth.

\section{Conclusion}

Discussion and analysis of the study reveal that among different existing media of communication and interaction, Smartphone applications have become growingly popular among the youth, especially the University students of Pakistan. Both the genders use this communication mean for different purposes. However, in the context of Pakistan, two facts are surfaced, i.e. the increase of Smartphone usage at personal levels as well as at political level. Male users frequently use this facility to get information relevant to politics and share their views on political affairs and development in the country. They also give opinion and propagate their political views through Smartphone applications. In Pakistan, though the facility is younger than other communication media. However, its applications and number of the users are growingly increasing very rapidly.

\section{References}

Amanda Lenhart, (2007). Teens and Social Media: Pew Internet and American Life Project: 1615 L ST., NW SUITE 700 WASHINGTON, D.C. 20036

Ansri, (2013).Pakistan Market Trends 2013: Online, Mobile, Social - Things Are About To Take Off. [Online Available at] http://ansr.io/blog/pakistan-market-trends- 2013-online-mobile-

Hermkens et al, (2011). Social media? Get serious: Understanding the functional building blocks of social media. Business horizons, 54(3), 241-251

Kaid, Lee (2004). Handbook of Political Communication Research: Lawrence Erlbaum Associates Publishers, Mahwah, New Jersey London, pp.1-21

Mobile Phone Subscribers in Pakistan, Date of access: 16/10/2015http://www.google.com/techlahore/?reqp=1\&reqr=.html

Kuznekoff et al (2013). The Impact of Mobile Phone Usage on Students Learning: Journal of Communication Education. Issue No. 62. P. 233-252. Taylor \& Frances Group

Mobile and Youth (2004). A Report on Study of Mobile Phone Usage among the Teenagers and Youth in Mumbai: Market Analysis and Consumer Research Organization, April, May, 2004, pp. 1-39

Murugaboopathi et al, (2012). Knowledge Management Through E-Learning: International Journal of Advance Research in Computer Science and Software Engineering, Volume 2, Issue \#9, ISSN 2277-128X, PP. 300-305 